\title{
CARACTERIZAÇÃO GEOMORFOLÓGICA E DO MEIO FÍSICO DA FOLHA ITAPOROROCA 1:25.000
}

\author{
Alexandre dos Santos Souza ${ }^{1}$ \\ Max Furrier ${ }^{2}$
}

Resumo: Objetiva-se com este trabalho, caracterizar as formas de relevo que compreende a Folha Itapororoca 1:25.000, situada na região Nordeste do Brasil. Os resultados, obtidos a partir da utilização de ferramentas de geoprocessamento, elaboração de perfis topográficos, confecção de mapas temáticos e cálculos morfométricos, demonstraram diversas peculiaridades geomorfológicas do terreno, possibilitando o detalhamento dos aspectos: morfológicos, geológicos, padrão da rede de drenagem e atuação dos fatores morfoestruturais e morfoesculturais atuantes na área. O terreno é parte integrante da faixa de dobramentos do ciclo Brasiliano, numa região onde é possivel averiguar compartimentos geomorfológicos distintos, fruto da interação entre os processos que atuam no modelado do relevo. A área é compreendida por um trecho que abrange a zona limítrofe entre os terrenos sedimentares e o afloramento cristalino, onde é possivel a visualização de basculamentos, superfícies tabulares, terrenos escalonados, vales distintos, rifteamento, linhas cumeadas (médias e suaves), padrão de drenagem anômala, canais extremamente retilíneos, bacia de drenagem dendrítica e recuo de cabeceiras, configurando nuances típicas de áreas afetadas por zonas de cisalhamento transcorrentes que estão presentes no substrato do Terreno Alto Pajeú (TAP).

Palavras-chave: Geomorfologia; Itapororoca; Morfotectônica; Parâmetros morfométricos.

\section{Characterization of the physical and geomorphological Itapororoca chart 1:25.000}

\begin{abstract}
This study aims to characterize the relief comprising Itapororoca Sheet (SB.25-Y-A$V$-4-NO) 1:25.000, located in the Northeast region of Brazil. The results, obtained from the use of geoprocessing tools, preparation of topographic profiles, preparation of thematic maps and morphometric calculations, showed various geomorphological peculiarities of the terrain, allowing the detailing of the aspects: morphological, geological, standard of drainage network and performance of morphostructural and morphosculptural factors acting in the area. The terrain is part of the fold belt of Brasiliano cycle, in an area where it is possible to determine distinct geomorphological compartments, result of the interaction between the processes that operate in the relief's modelling. The area is comprised of a stretch that covers the boundary zone between the sedimentary terrains and crystalline outcrop, where it is possible to visualize tiltings, tabular surfaces, staggered terrains, distinct valleys, rifting, ridges lines (medium and soft), anomalous drainage pattern, extremely straight channels, dendritic drainage basin and headwaters retreat, setting nuances typical of areas affected by transcurrent shear zones that are present on the substrate of Terreno Alto Pajeú (TAP).
\end{abstract}

Keywords: Geomorphology, Itapororoca, Morphotectonics, Morphometric parameters.

\footnotetext{
${ }^{1}$ Graduado em Geografia pela Universidade Federal da Paraíba. Mestrando em Geografia, Universidade Federal da Paraíba - UFPB. E-mail: alesougeo@gmail.com

${ }^{2}$ Professor Adjunto do Departamento de Geociências da Universidade Federal da Paraíba - UFPB. E-mail: max.furrier@hotmail.com
} 


\section{INTRODUÇÃO}

Estudar as formas do relevo tem enorme relevância para a sociedade, sob vários aspectos, quer sejam científicos, econômicos e/ou sociais. Nessa perspectiva, tem-se, no estudo das interações entre os processos formadores e modeladores do relevo a partir de cartas topográficas e estudos quantitativos e qualitativos, um meio eficaz e acessível pelo qual é possível interpretar as peculiaridades físicas de um terreno.

O relevo terrestre apresenta formas distintas que interagem por meio de processos externos e internos, também conhecidos como forças endógenas e exógenas. Segundo Penha (2007), tais processos dão origem e modelam diversas morfologias presentes na superfície do planeta, cuja história geológica já superou quatro bilhões de anos.

Nesta perspectiva, este trabalho dedica-se a caracterizar, a partir de premissas geomorfológicas e mapas temáticos e cálculos morfométricos, as formas de relevo que configuram uma pequena massa continental compreendida pela carta topográfica de Itapororoca 1:25.000, região Nordeste do Brasil. Nessa região, Santos et al., (2004) averiguaram que o relevo não ascende cotas altimétricas superiores a 200 metros, compreendendo uma porção situada na depressão sublitorânea do Estado da Paraíba, onde predominam superfícies colinosas classificadas como suaves onduladas, onduladas, com presença de tabuleiros e vales distintos, configurando um agregado de feições situadas numa porção limítrofe da faixa de dobramentos do ciclo Brasiliano.

A região apresenta uma estrutura litosférica que demonstra estar condicionada por processos tectônicos integrados aos fatores exógenos. Dessa forma, justifica-se a necessidade de uma análise detalhada do terreno, a partir da utilização de índices morfométricos e mapas temáticos, no intuito de fornecer dados que tenham por finalidade caracterizar a morfotectônica ocorrida na área e auxiliar no planejamento do espaço geográfico da região.

Para Suguio (2000), o estudo das relações existentes entre as feições fisiográficas e as estruturas neotectônicas de uma região podem ser denominados de morfotectônica. Sendo assim, balizada nessa premissa, a análise apresentada neste trabalho detalha as peculiaridades geomorfológicas e geológicas da área em questão, procurando informações que estejam atreladas às evidências tectônicas.

Nessa perspectiva, de acordo com Guerra e Guerra (1997), torna-se de grande relevância o estudo das formas de relevo e o conhecimento das bases litológicas, buscando no subsolo 
explicações que estejam correlacionadas aos agentes modeladores que atuam de maneira integrada dando origem às variadas feições morfológicas.

\section{MATERIAIS E METODOLOGIA}

A matriz de elaboração dos produtos de análise da área apresentados nesta pesquisa foi a carta topográfica de Itapororoca (SB.25-Y-A-V-4-NO), desenvolvida pelo Serviço de Cartografia da Divisão de Recursos Naturais da Sudene (1974), na escala de 1:25.000, com equidistância entre as curvas de nível de $10 \mathrm{~m}$.

Um procedimento imprescindível à proposta metodológica e desenvolvimento do trabalho foi a digitalização da carta em formato JPEG, o que permitiu sua importação para o software livre DraftSight, por meio do qual foi possível a vetorização das isolinhas, pontos cotados e traçado dos canais de drenagem. A exportação dos dados para o Spring 5.1.7 permitiu a elaboração da carta hipsométrica, clinográfica e Modelo Digital do Terreno (MDT).

Outra técnica empregada amparou-se no cálculo morfométrico Razão Fundo/Altura do Vale (RFAV). Este método consiste de técnica utilizada há algumas décadas nos estudos geomorfológicos e que, em função dos avanços tecnológicos, têm sido sucessivamente ampliados, representando método eficaz, pelo qual os processos morfogenéticos podem ser estudados com a confecção de modelos escalares que criem condições para a análise experimental (CHRISTOFOLETTI, 1980).

Outros elementos fundamentais empregados na pesquisa e confecção de mapeamentos da análise da área foram:

$\checkmark$ Consulta do mapa geológico do Estado da Paraíba, na escala 1:100.000.

$\checkmark$ Consulta do levantamento exploratório dos solos do Estado da Paraíba, disponibilizado por ela Empresa Brasileira de Pesquisa Agropecuária (BRASIL, 1972), na escala 1:500.000.

$\checkmark$ Consulta ao mapa de classes de capacidade de uso das terras, escala 1:200.000, disponibilizado pela Agência Executiva de Gestão das Águas do Estado da Paraíba (Aesa), em conjunto com a Secretaria de Estado da Ciência e Tecnologia e do Meio Ambiente (Sectma), procedimento que possibilitou uma visão, em plano cartográfico, das principais características dos solos da região.

$\checkmark$ Confecção de perfis topográficos ao longo de orientações longitudinais e latitudinais que contam a área de estudo sobre algumas das coordenadas Universal 
Transversa de Mercator (UTM), onde o plano morfológico se mostrou bastante distinto, com auxílio dos programas Excel e CorelDRAW.

$\checkmark$ Visitas de campo e registros iconográficos em alguns trechos da área de estudo.

\section{Localização e caracterização físico-ambiental da área de estudo}

A carta topográfica de Itapororoca está situada na porção oriental do Estado da Paraíba, Região Nordeste do Brasil. Seus limites estão definidos pelos paralelos: 60 45’ 00" ao norte; e

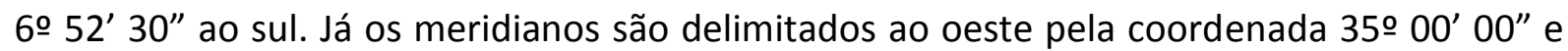

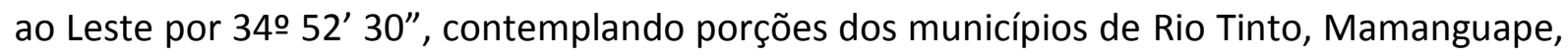
Itapororoca, Cuité de Mamanguape, Capim e Curral de Cima, todos integrados à Microrregião do Litoral Norte Paraibano.

A área corresponde a uma porção de terras baixas na zona limítrofe entre os terrenos sedimentares e o afloramento do embasamento cristalino comuns à faixa litorânea e sublitorânea oriental do Brasil, onde podem ser encontradas áreas cristalinas do PréCambriano, situadas entre as grandes bacias sedimentares intracratônicas (Figura 1), cujos terrenos apresentam peneplanos, basculamentos e eventuais depressões tectônicas, que Ab’Sáber (1964) definiu como relevos policíclicos.

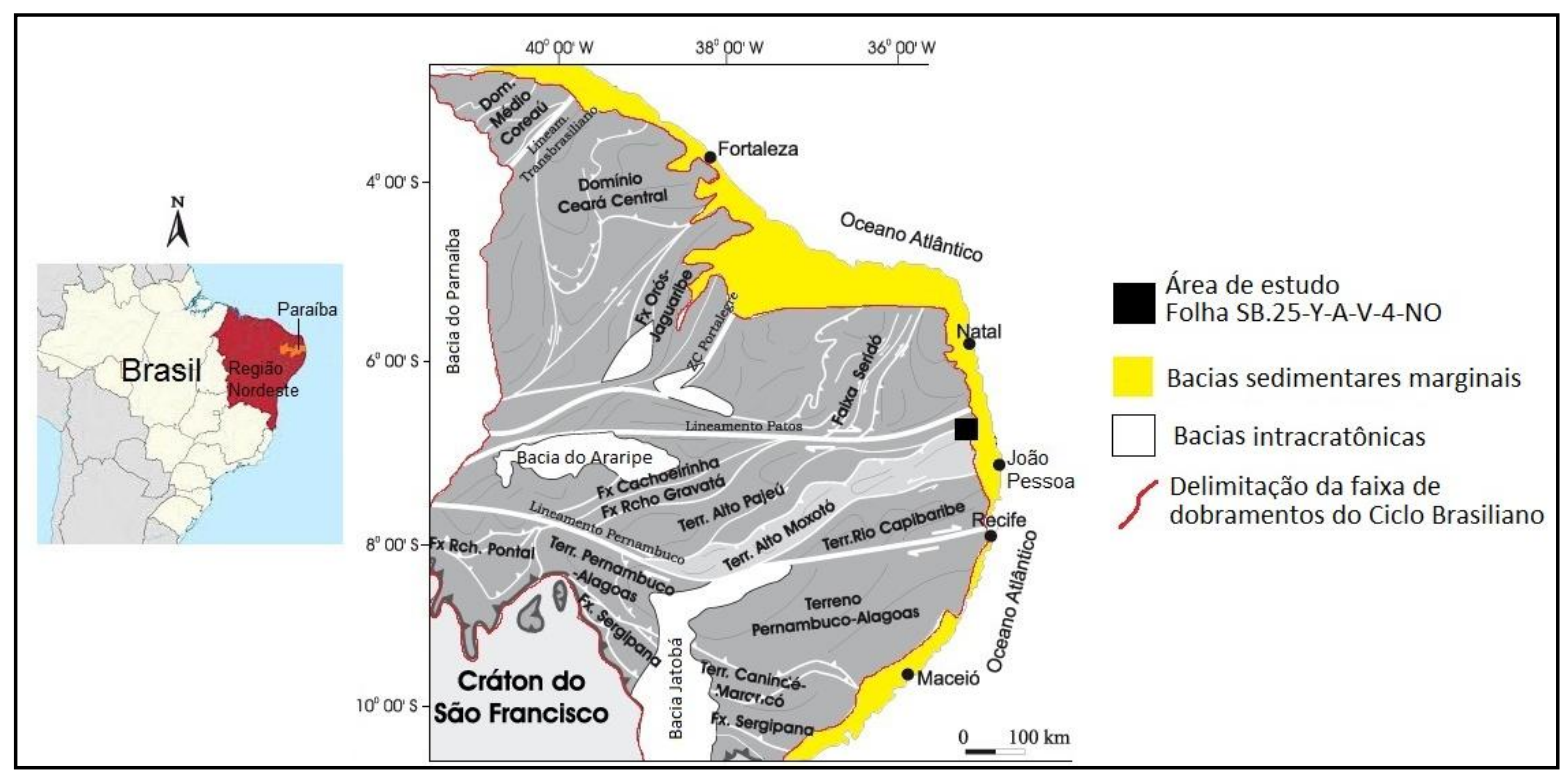

Figura 1 - Localização da área de estudo entre os terrenos sedimentares e cristalinos. Fonte: Adaptado de Santos, et al. (2004). 


\section{Geologia}

De acordo com Serviço Geológico do Brasil (CPRM, 2002), o arcabouço geológico da Paraíba é constituído predominantemente por "rochas pré-cambrianas, que abrangem cerca $80 \%$ do seu território, sendo complementado por bacias sedimentares, rochas vulcânicas cretáceas, coberturas plataformais paleógenas/neógenas e formações superficiais quaternárias".

Para Almeida et al. (1977 apud BRASIL, 2002), a área pré-cambriana corresponde a partes da Província Borborema, um cinturão orogênico meso/neoproterozóico que contempla partes da Região Nordeste, indo de Sergipe até a porção oriental do Piauí.

$\mathrm{Na}$ Paraíba são reconhecidos diversos segmentos dos domínios (subprovíncias, superterrenos): Cearenses, Rio Grande do Norte e Transversal (BRASIL, 2002). Uma das feições geológicas mais marcantes da compartimentação crustal do território paraibano é o Lineamento Patos, apresentado como um extenso bloco de embasamento fortemente retrabalhado no ciclo Brasiliano-Panafricano, cujos detalhes morforestruturais são detalhados em estudos de Brito Neves et al. (1995, 2001), Santos et al. (2004), entre outros. O Lineamento Patos praticamente divide o Estado da Paraíba em dois superterrenos.

A região estudada é parte integrante de um arcabouço litoestratigráfico situado entre os Lineamentos Patos e Pernambuco, na megaestrutura da Zona Transversal, mais precisamente no Terreno Alto Pajeú (TAP), cuja estrutura é composta por unidades gnáissicas paleoproterozóicas, metavulcanossedimentares e metaplutônicas e granitóides, que estão arranjadas entre zonas de cisalhamento transcorrentes associadas ao evento Brasiliano (SANTOS et al., 2004).

Para Hasui e Ponçano (1978) e Asmus e Ponte (1973), o TAP foi afetado por movimentações no Cenozóico, que, de acordo com Brito Neves et al. (2004), reativou antigas linhas de falhas do Proterozóico. Segundo Serviço Geológico do Brasil (CPRM, 2002), o Terreno do Alto Pajeú possui de médio a alto grau de metamorfismo do tipo metagrauvacas, com diversas intercalações de rochas vulcânicas, ortognaisses diversos de natureza granítica e granodiorítica. De acordo com Brito Neves et al. (2001), no TAP são encontradas zonas de cisalhamento na porção sul do Lineamento Patos.

De acordo com o Mapa Geológico da Paraíba (SANTOS 2002), verificou-se uma litologia que congrega rochas do tipo: Granitóide de quimismo indiscriminado (Nүi); Gnássico-Migmatito (Pgm/py - retrabalhados no Meso e Neoproterozóico); Vulcânica Félsica Itapororoca (Ki sem dados geocronológicos, sendo atribuída uma idade Cretácea por correlação com o vulcanismo da Bacia do Cabo); coberturas elúvio-coluviais (Qe), aluviões ( $Q$ a - representados 
pelos aluviões do rio Mamanguape); e da Formação Barreiras (ENb - apresentando estratificações tabulares/planares de forte ângulo).

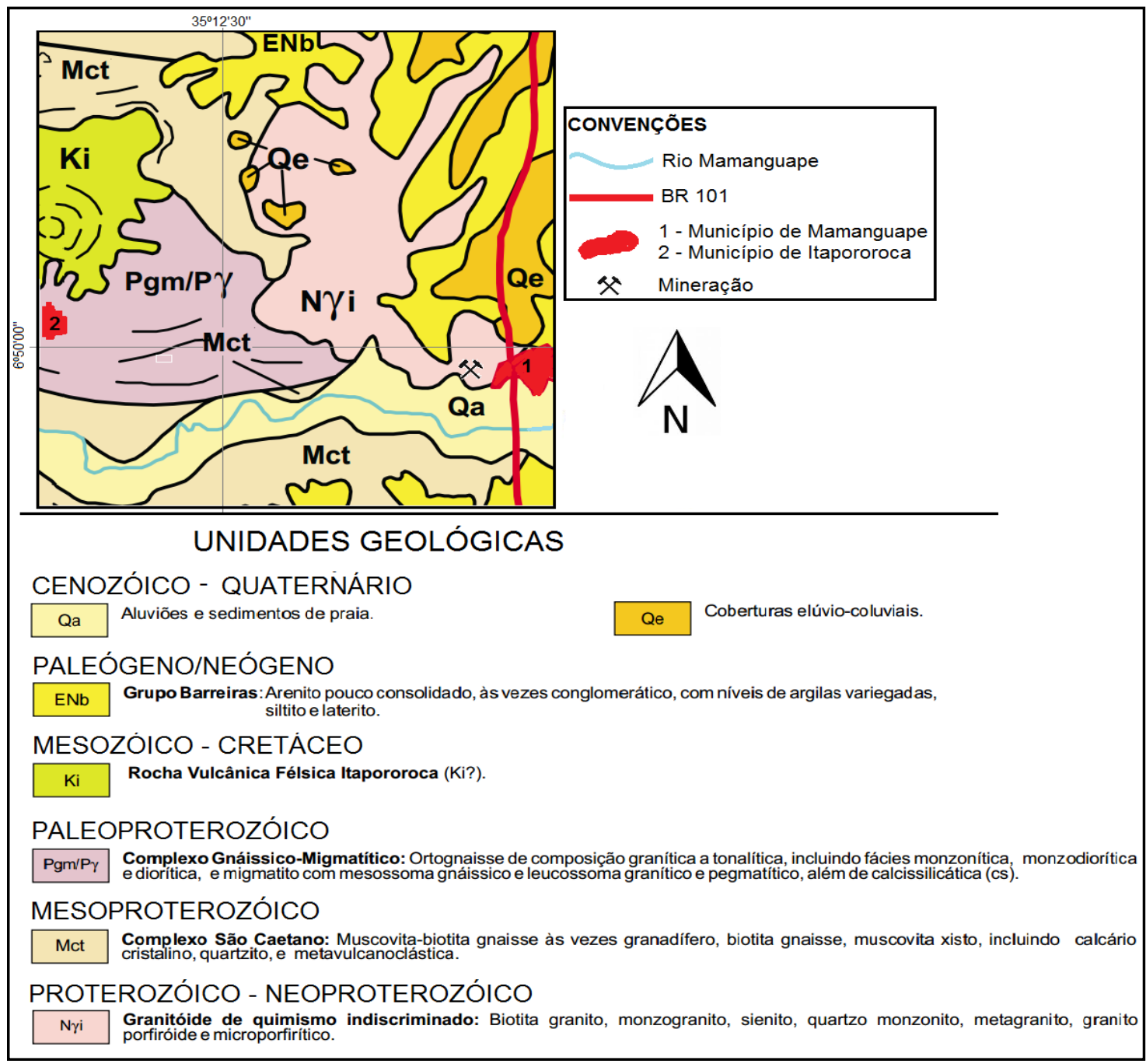

Figura 2 - Mapa Geológico da área. Fonte: Adaptado de CPRM (2002).

Nessa perspectiva, torna-se relevante entender o relevo a partir das alterações geradas por tensões de natureza neotectônica. Para Maia e Bezerra (2011), numa abordagem geomorfológica que objetive analisar processos morfogenéticos e morfoevolutivos, é de suma importância que se considerem os aspectos da neotectônica.

A situação geológica da região também foi detalhada por Brito Neves et al. (2008), o que possibilitou elucidar questões de natureza geológicas e geofísicas presentes na área, uma vez que os autores expuseram uma análise da Folha Guarabira 1:100.000, terreno que comporta a Folha Itapororoca 1:25.000. 
Em conformidade com as análises de Brito Neves et al. (2008), observou-se que, na região, ocorrem inúmeros realces de reativações tardias influenciadas pelo Lineamento Patos e, ainda, a falha normal que alinha o baixo curso do rio Mamanguape.

Já no baixo curso do rio Mamanguape, é encontrado o compartimento litosférico regional, que confina o gráben do rio Mamanguape, cujos processos formadores foram detalhados por Brito Neves et al. (2004, 2008), ressaltando que, no que tange à área de estudo desta pesquisa, em particular, tem-se o rio Mamanguape confinado num rifteamento que abrange seu médio curso.

$\mathrm{Na}$ borda oriental da área de estudo conforme mapa geológico, Santos (2002), ocorre a predominância de sedimentos areno-argilosos mal consolidados da Formação Barreiras (FURRIER et al., 2006) e das coberturas elúvio-coluviais (Figura 4).

Sobre a Formação Barreiras, Bezerra et al.(2006) apontam, no trabalho dos autores citados anteriormente, que este "trata das relações entre Geomorfologia e tectônica, conforme observações feitas na faixa sedimentar costeira do Estado da Paraíba, onde tabuleiros litorâneos apresentam variações de altitude e nível de erosão", ressaltando-se que alguns desses aspectos poderão ser observados na análise dos perfis topográficos mais adiante.
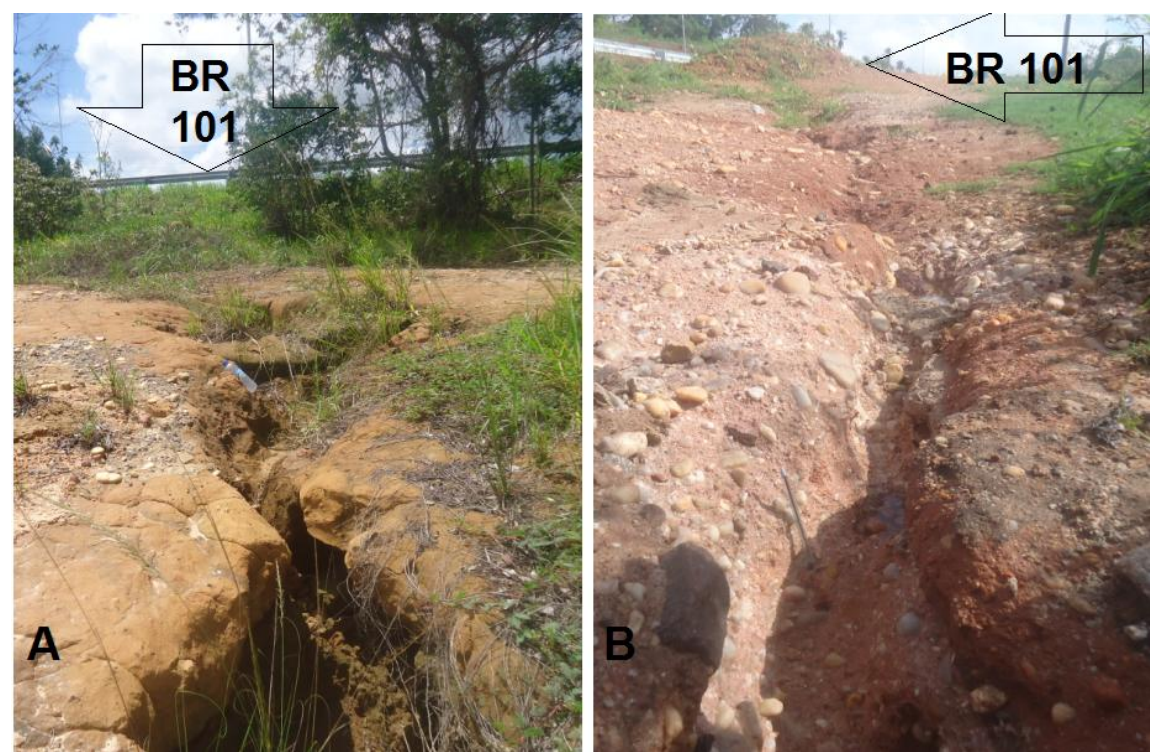

Figura 4 - (A) Formação de ravina sobre os sedimentos mal consolidados (ENb) na cabeceira do rio Santa Cruz (extremo NE da área de estudo), distando apenas $15 \mathrm{~m}$ da margem da BR 101; (B) Ocorrência de ravinas sobre a cobertura elúvio-coluviai na margem direita da BR 101, próximas à ponte do rio Mamanguape. Observar, nos cantos superiores de ambas as fotografias, a proximidade com o guard rail da estrada.

Fotos: Souza (2013). 


\section{o Clima}

O clima da região é Tropical Quente Úmido do tipo As', segundo a classificação de Köppen, com chuvas de outono-inverno. Nessa região as chuvas são formadas pelas massas atlânticas trazidas pelos ventos alísios de sudeste.

De acordo com o Serviço Geológico do Brasil (CPRM, 2005), mediante informações apresentadas pelo Projeto Cadastro de Fontes de Abastecimento por Água Subterrânea, que elaborou diagnóstico técnico dos municípios dos estados da Região Nordeste, há uma grande similaridade nos índices de precipitação média anual nos municípios que abrangem a Folha Itapororoca, (Rio Tinto, Mamanguape, Cuité de Mamanguape, Itapororoca, Capim e Curral de Cima), em torno de 1.634,2 $\mathrm{mm}$.

\section{O Solo}

Compreender as propriedades dos solos é de grande relevância para o uso e ocupação adequado desse recurso fundamental ao desenvolvimento social e econômico. No que tange à área de estudo, a consulta ao Levantamento Exploratório dos Solos do Estado da Paraíba (EMBRAPA, 1972) e Classes de Capacidade de Uso das Terras, disponibilizado pela Agência Executiva de Gestão das Águas do Estado da Paraíba (Aesa), em conjunto com a Secretaria de Estado da Ciência e Tecnologia e do Meio Ambiente (Sectma), possibilitou uma visão, em plano cartográfico, das principais características dos solos da região.

Vale salientar que os mapeamentos apresentados pelos órgãos oficiais supracitados apresentam uma perspectiva escalar diferente da Folha Itapororoca, neste último caso, 1:25.000, considerada uma microescala, e nos primeiros, 1:500.000 e 1:200.000, respectivamente, representando o que Argento (2007) define como macroescalas.

De acordo com o de reconhecimento dos solos da Folha Itapororoca (SB.25-Y-A-V-4-NO) 1:25.000 (Figura) e definições do Boletim Técnico no 15 da Embrapa (1972), os tipos de solos predominantes da área de estudo podem ser assim descritos:

$\checkmark$ Podzólico Vermelho Amarelo (PV3) (p. 585): solos com variação acinzentada com fragipã, possui textura indiscriminada da fase cerrado, em relevo plano e Podzol Hidromórfico fase cerrado, também de relevo plano.

$\checkmark$ Podzólico Vermelho Amarelo Equivalente Eutrófico (PE12) (p. 250): possui horizonte A proeminente com fragipã e textura argilosa com perfis menos profundos; saprolito proveniente de rochas do Pré-Cambriano com influência de material sedimentar do Terciário; o relevo é ondulado em forma de colinas. 
$\checkmark$ Areias Quartzosas Distróficas (AQd) (p. 47-48): solos areno-quartzosos, profundos, com baixos teores de argila e fertilidade natural muito baixa; a unidade ocorre na Zona do Litoral e da Mata, em áreas de relevo plano típico do Tabuleiros Costeiros situados ao norte do rio Mamanguape; o material originário destes solos deriva de sedimentos areno-quartzosos da Formação Barreiras do Terciário; são excessivamente drenados e apresentam horizonte A fracamente desenvolvido.

$\checkmark$ Solos Aluviais Eutróficos (Ae) (p. 622): possui textura indiscriminada; relevo plano de várzea.

É importante ressaltar que a Embrapa $(1999,2006)$, por meio do Centro Nacional de Pesquisa de Solos, desenvolveu uma nova classificação dos solos brasileiros - Sistema Brasileiro de Classificação de Solos (SiBCS).

Quadro 1 - Classificação anterior e atualizada dos solos

\begin{tabular}{|c|c|c|}
\hline $\begin{array}{c}\text { Classificação anterior } \\
\text { (BRASIL, 1972) }\end{array}$ & $\begin{array}{c}\text { Nova classificação } \\
\text { (EMBRAPA, 1999, 2006) }\end{array}$ & Nova simbologia \\
\hline $\begin{array}{c}\text { Podzólico Vermelho Amarelo } \\
\text { variação Acinzentada com fragipã }\end{array}$ & $\begin{array}{c}\text { Argissolo Acinzentado Distrófico } \\
\text { fragipânico }\end{array}$ & PACd \\
\hline $\begin{array}{c}\text { Podzólico Vermelho Amarelo } \\
\text { com fragipã }\end{array}$ & $\begin{array}{c}\text { Argissolo Amarelo Distrófico } \\
\text { arênico fragipânico }\end{array}$ & PAd \\
\hline Areias Quartzosas & Neossolos Quartzarênicos & $\mathrm{RQ}$ \\
\hline Solo Aluvial Eutrófico & Neossolos Flúvicos & $\mathrm{RY}$ \\
\hline
\end{tabular}

Fonte: Adaptado de Brasil (1972) e Embrapa (1999, 2006).

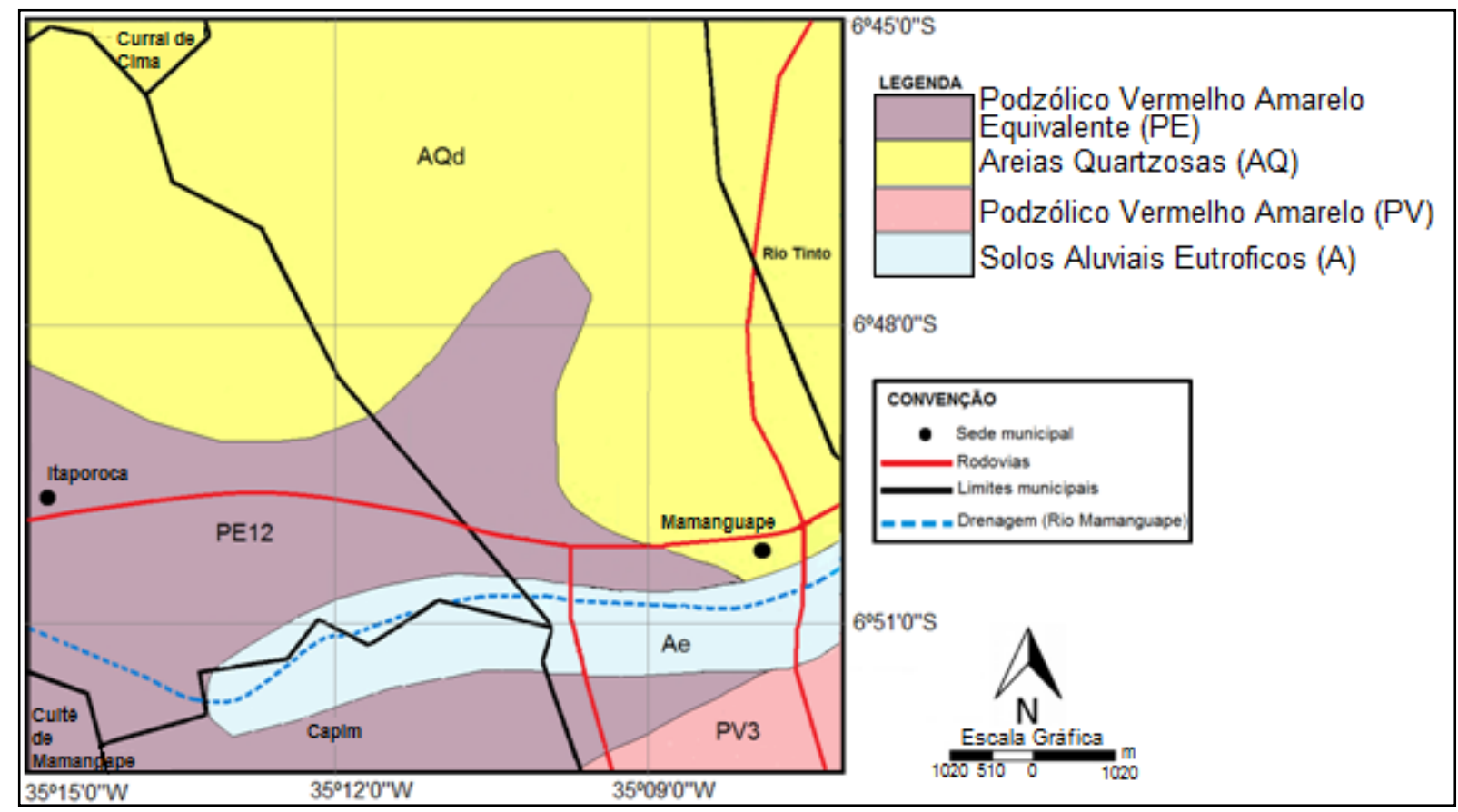

Figura 5 - Mapa de solos da área.

Fonte: Levantamento Exploratório-Reconhecimento de Solos do Estado da Paraíba, Brasil (1972), com adaptações. 


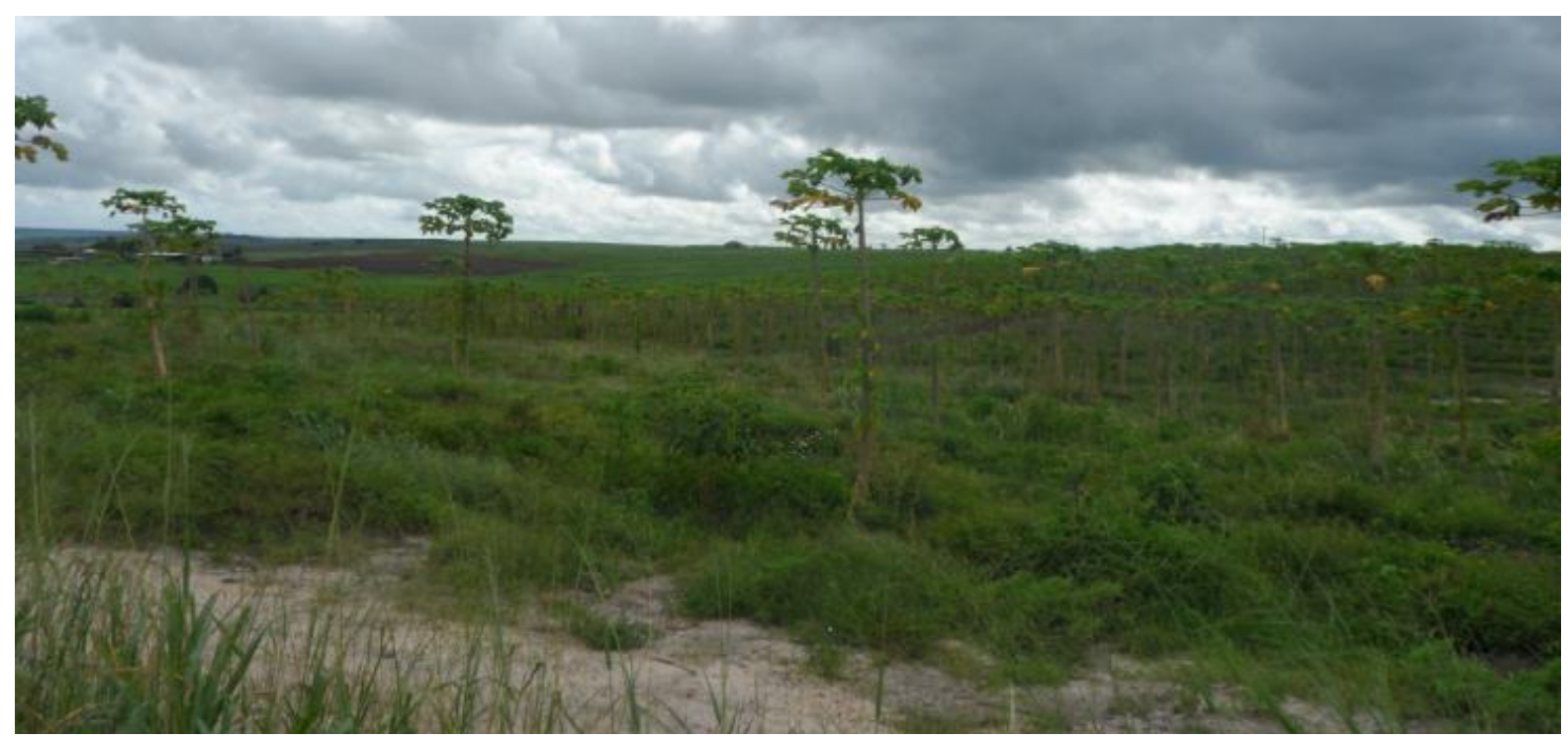

Figura 6 - Lavoura permanente de mamão no município de Mamanguape

Nota: Observar o relevo suavemente ondulado e o solo arenoso.

Foto: Souza (2013)

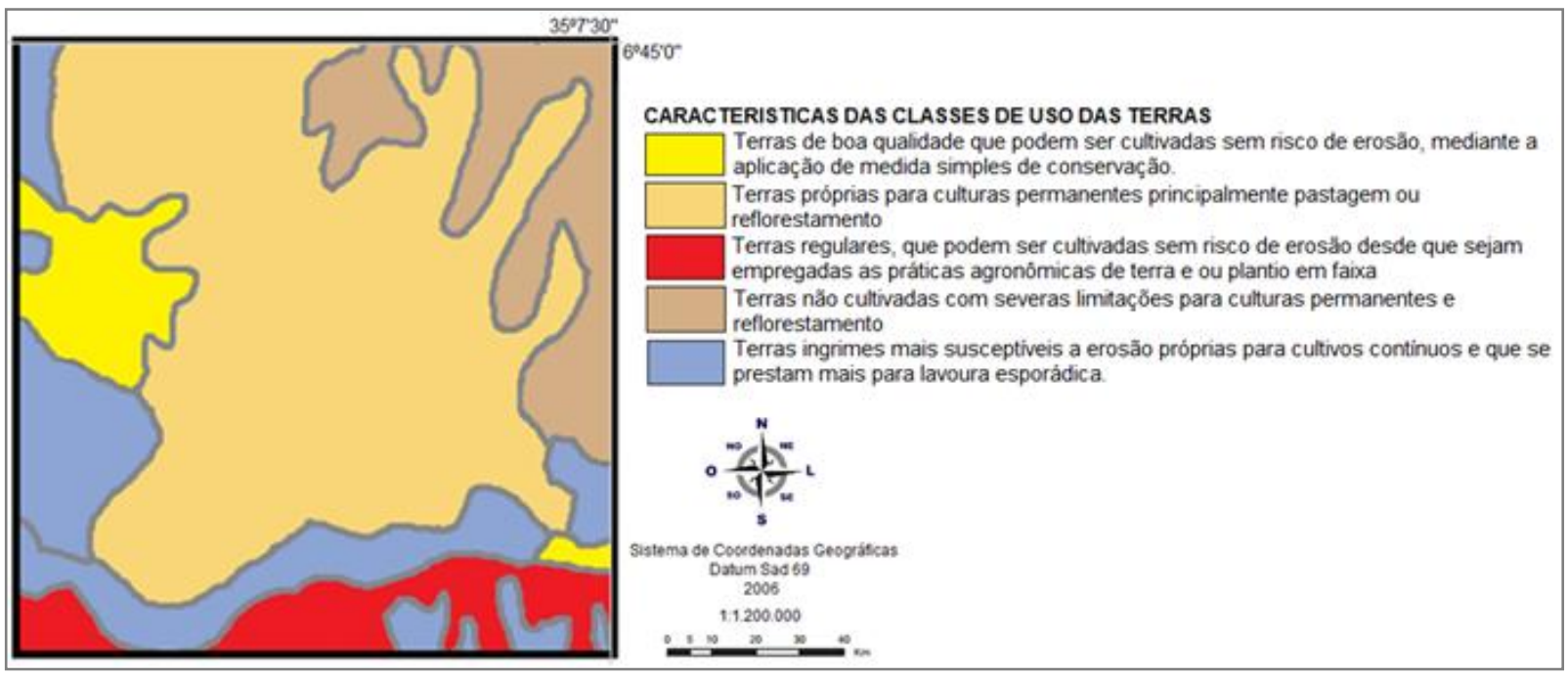

Figura 1 - Mapa das classes de capacidade de uso das terras.

Fonte: Adaptado de Aesa (2004).

\section{Morfologia e Rede de Drenagem}

\section{Carta clinográfica}

Para De Biase (1970), a utilização da carta clinográfica é de grande relevância em trabalhos dentro das Ciências da Terra que se dedicam ao planejamento de áreas urbanas e agrárias, pois fornece representações gráficas da orientação de vertentes, entre outros aspectos, possibilitando "uma melhor compreensão e um equacionamento dos problemas que ocorrem no espaço analisado". Para Christofoletti (2007), a confecção da carta de declividades, associada à rede canais de drenagem fluvial, são instrumentos valiosos para o planejamento 
do solo.

A elaboração da carta clinográfica da Folha Itapororoca (SB.25-Y-A-V-4-NO) seguiu os critérios de classificação propostos por Herz e De Biase (1989) (Tabela 1), que vincularam essas classes a limites usados internacionalmente, bem como a pesquisas nacionais e leis em vigência no Brasil.

Tabela 1 - Classes de declividade

\begin{tabular}{cc}
\hline Percentualidade & Graus \\
\hline$<12 \%$ & $<7,25$ o \\
$12 \%-30 \%$ & 7,25 o -17 o \\
$30 \%-47 \%$ & 17 o -25 o \\
$47 \%-100 \%$ & 25 o -45 o \\
$>100 \%$ & $>45$ o \\
\hline
\end{tabular}

Fonte: Herz e De Biasi (1989).

A carta clinográfica e observação de campo (Figura 9) permitiu a observação das áreas com maior e menor grau de declividade, sendo que as frequências de valores entre $47-100 \%$ se concentram nos seguintes trechos:

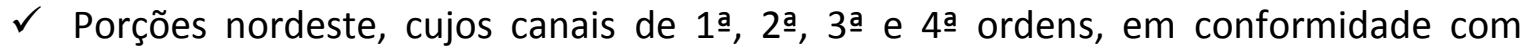
ordenação proposta por Straler (1962 apud CHRISTOFOLETTI, 1980), tem como característica fisiográfica padrões paralelos e retilíneos, exibindo, de forma conspícua, o entalhamento dos respectivos canais.

$\checkmark$ Porção noroeste, em alguns canais mais ao norte, com drenagem radial centrífuga e condicionada pelo domo erodido da rocha vulcânica félsica Itapororoca (vide MDT e Mapa Geológico).

$\checkmark$ Extensão meridional da carta, com declividades acentuadas nas encostas que circundam o Riacho Leite Mirim, este com forte inflexão de 90‥ Além disso, vários outros trechos dos canais que afluem para margem sul do Rio Mamanguape também apresentam declividades acentuadas.

\section{Modelo Digital do Terreno (MDT)}

O Modelo Digital do Terreno (MDT) (Figura 2) possibilitou a observação, em um plano especial, de quatro unidades morfológicas dominantes. Como auxílio de interpretação dessas unidades morfológicas e parâmetro basilar, utilizou-se o modelo estabelecido por Ross (1992), que estabelece as unidades taxonômicas de classificação do relevo.

A unidade 1 está representada por estruturas de topos tabulares sobre o domínio da Formação Barreiras, cujos vales encaixados e dissecados seguem sentidos discordantes da 
drenagem regional. A unidade 2 apresenta uma complexa rede de canais que drenam principalmente para os rios Seco e Mamanguape, evidenciando uma extensa área de relevo de colinas médias e suavizadas. Já a unidade 3 é representada pela porção oriental do domo erodido do Episódio Vulcânico Itapororoca, cujo gradiente altimétrico e morfologia demonstram exercer forte influência na drenagem dos afluentes da borda oeste da área. $E$, por fim, mas não menos importante, a unidade 4 abrange a planície de rio Mamanguape, principal rio da região para onde é drenada toda rede hidrográfica da região.

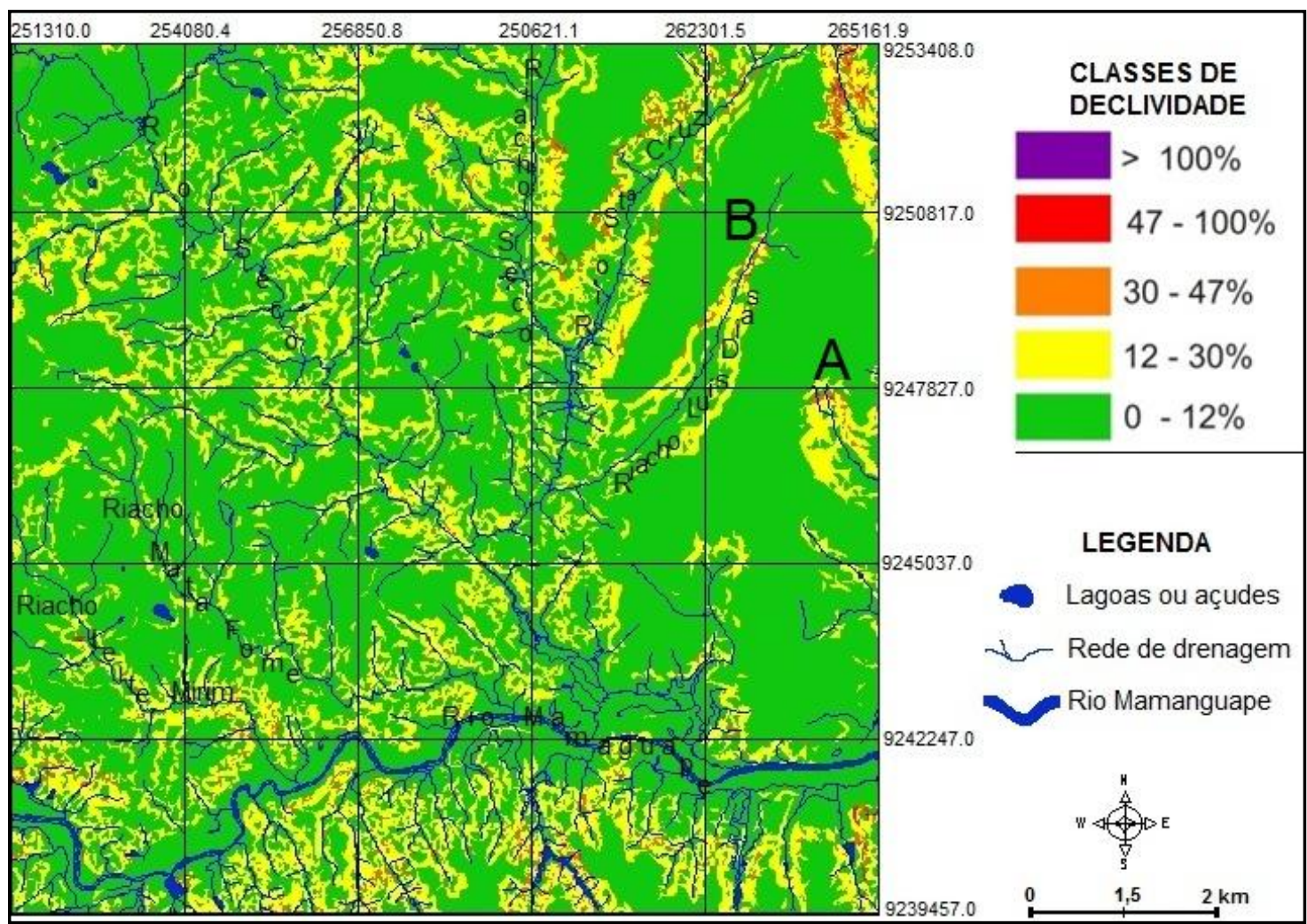

Figura 8 - Carta clinográfica da área de estudo. Nos pontos A e B foram feitos registros de declividades maiores que 47\%. Org.: Souza (2013).

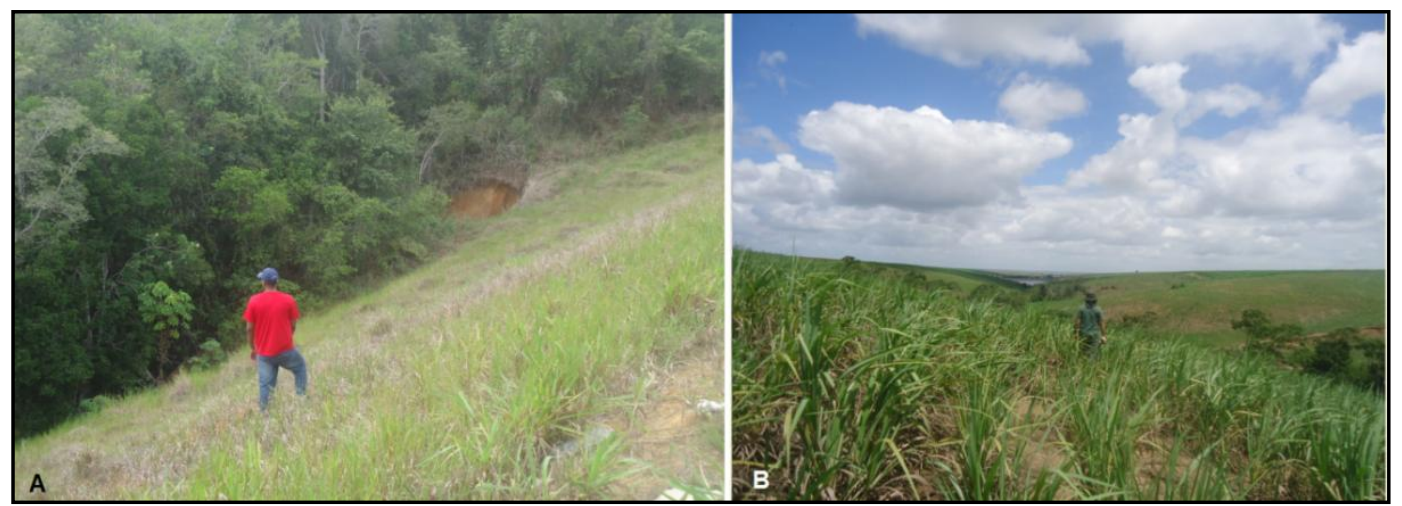

Figura 9 - Encostas em Rio Tinto e no vale do Riacho Luís Dias. (A) Encosta com alto grau de declividade na margem da BR 101, na altura do município de Rio Tinto. Apesar da presença de vegetação de grande porte, há ocorrencia de movimento de massa; (B) Encosta do vale do Riacho Luís Dias proximo à cabeceira que está ocupada por monocultura de cana-de-açucar. Nesse trecho o canal fluvial apresenta ponto de represamento.

Fotos: Souza (2013). 


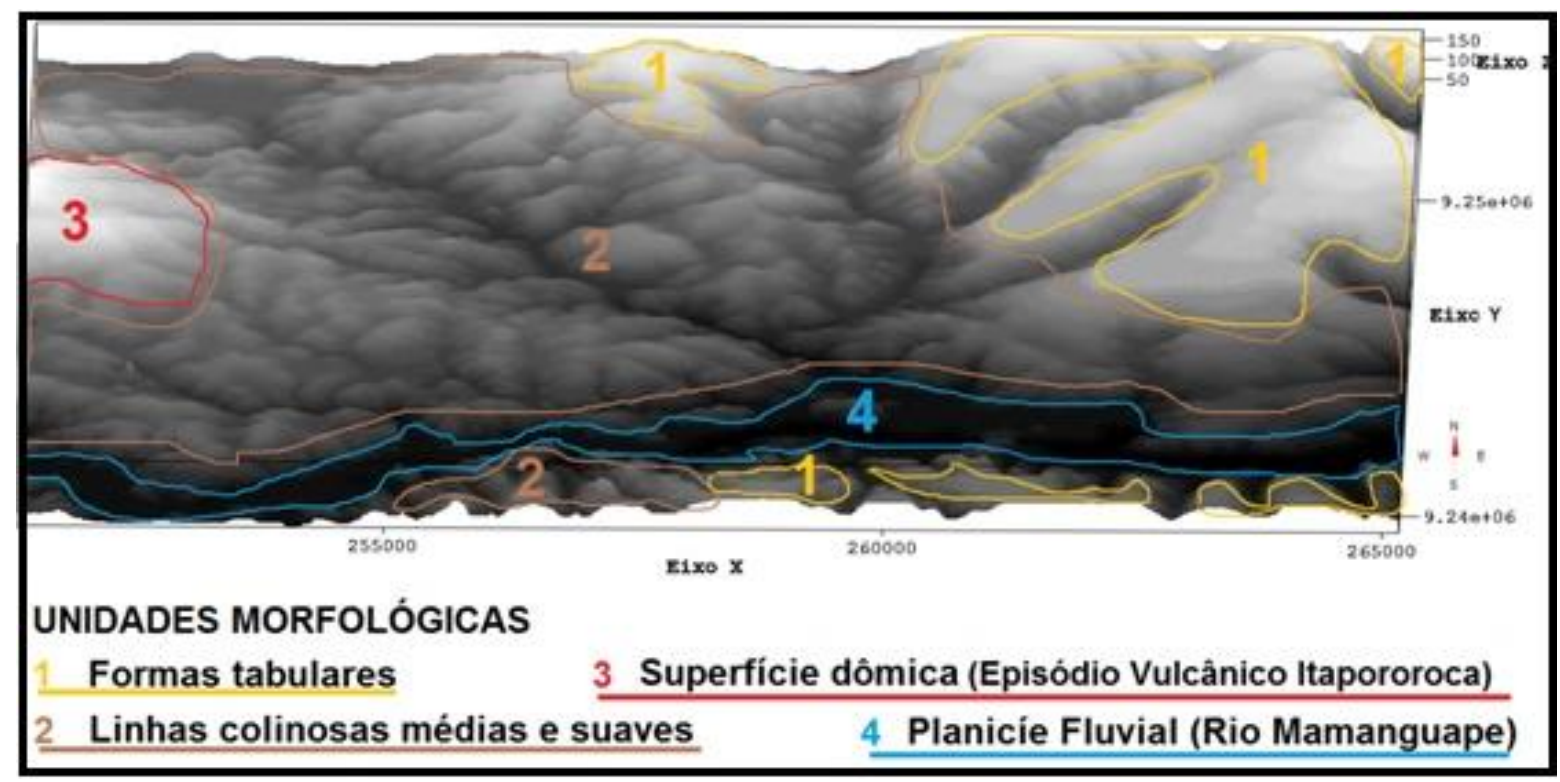

Figura 2 - Modelo Digital do Terreno (MDT)

Org.: Souza (2013).

\section{Análise dos perfis topográficos}

O perfil A, (Figura 11), orientação N/S, traçado na borda ocidental da carta, possui número significativo de vales em toda a extensão do terreno, demonstrando uma topografia falhada, com drenagem visivelmente controlada pelo gradiente altimétrico do alto topográfico do Episódio Vulcânico Itapororoca, constituído pela rocha Vulcânica Félsica Itapororoca (Ki). Na porção sul, destaca-se o rifteamento do rio Mamanguape, onde ocorre um aluvionamento com presença de blocos soerguidos nas guarneces e bastante dissecados por processo erosivos.

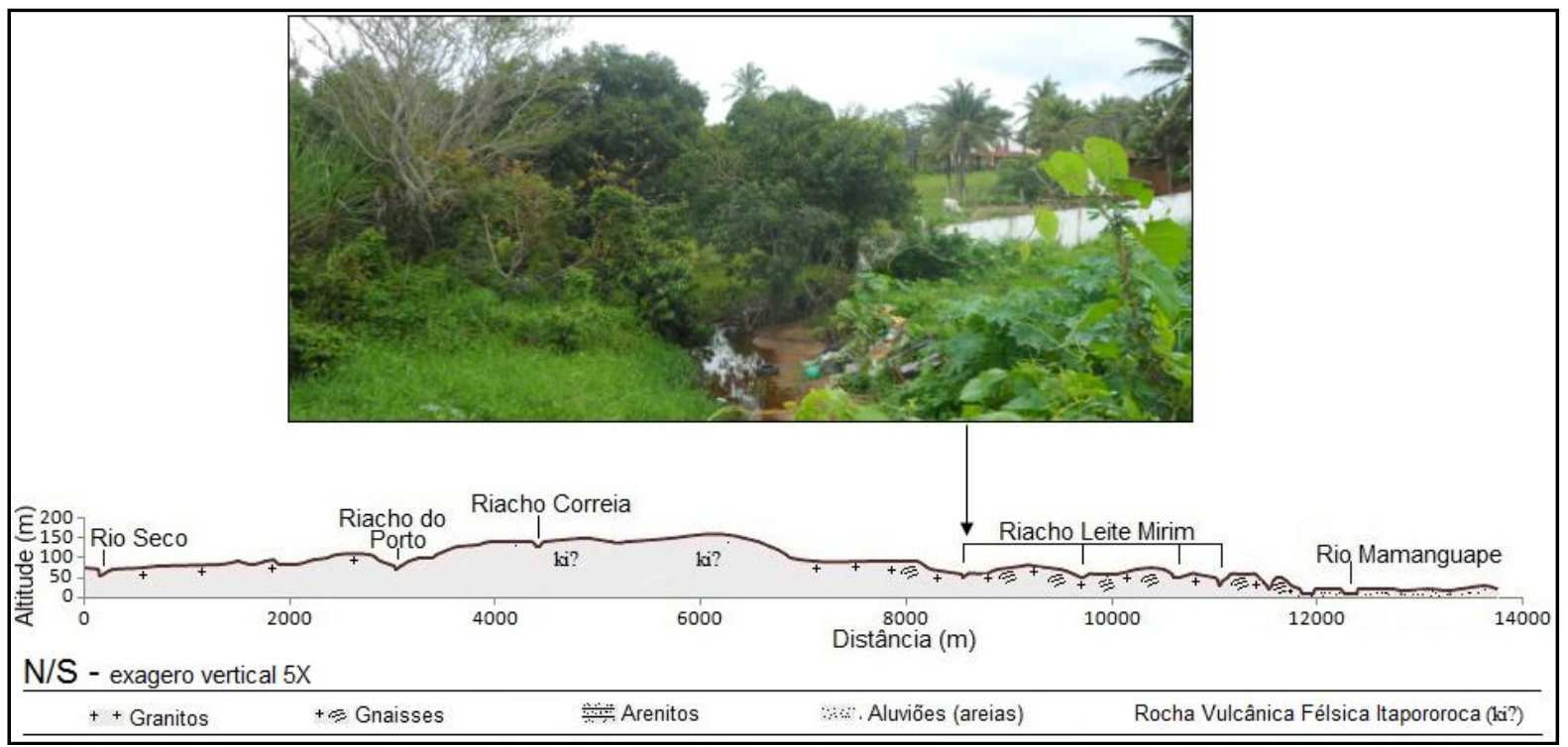

Figura 11 - Perfil A - UTM 252000. Observar a margem do Riacho Leite Mirim, nas proximidades da área urbana do munícipio de Itapororoca, indícios de contaminação por residuos sólidos. 
O perfil B, (Figura 12) orientação N/S, delineado na borda oriental da carta, apresenta uma morfologia aplainada, pouco dissecada e levemente ondulada nos 5,5 km iniciais da porção norte, com extensa área escalonada em degraus que segue para a porção sul em direção ao vale do rio Mamanguape, onde, também, foram encontrados basculamentos e superfícies tabulares comuns da Formação Barreiras, que, segundo Furrier et al. (2006), apresenta aspectos estruturais e morfológicos semelhantes a um teclado de piano com a formação de horstes e grábens.

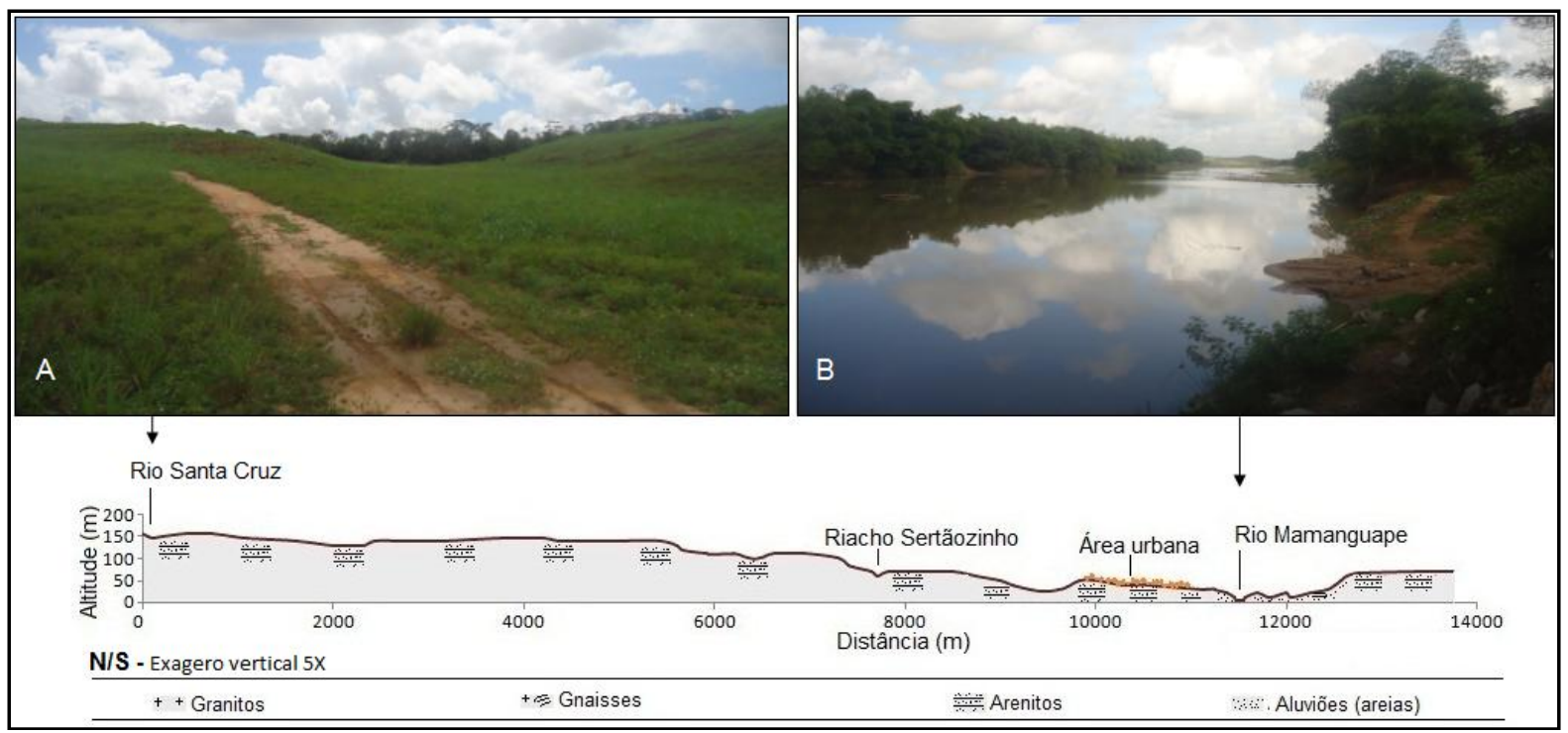

Figura 12 - Perfil B - UTM 264000. Observar os detalhes na cabeceira do rio Santa Cruz completamente ocupada pela monocultura de cana-de-açúcar (A), e o rio Mamanguape com parte da mata ciliar preservada, mas com pontos visíveis de assoreamento (B).

O perfil C, (Figura 13), orientação W/E, porção norte da carta, inicia-se com a formação do domo erodido do Episódio Vulcânico Itapororoca. No percurso do seu traçado estão projetados os principais canais que afluem para o rift que confina o médio curso do rio Mamanguape. Nesse perfil foi averiguado o maior gradiente altimétrico da carta, chegando a superar $160 \mathrm{~m}$ em alguns pontos, compreendendo blocos escalonados em direção W/E, ondulados e desgastados por processos de erosivos, principalmente na área de abrangência da Formação Barreiras. 


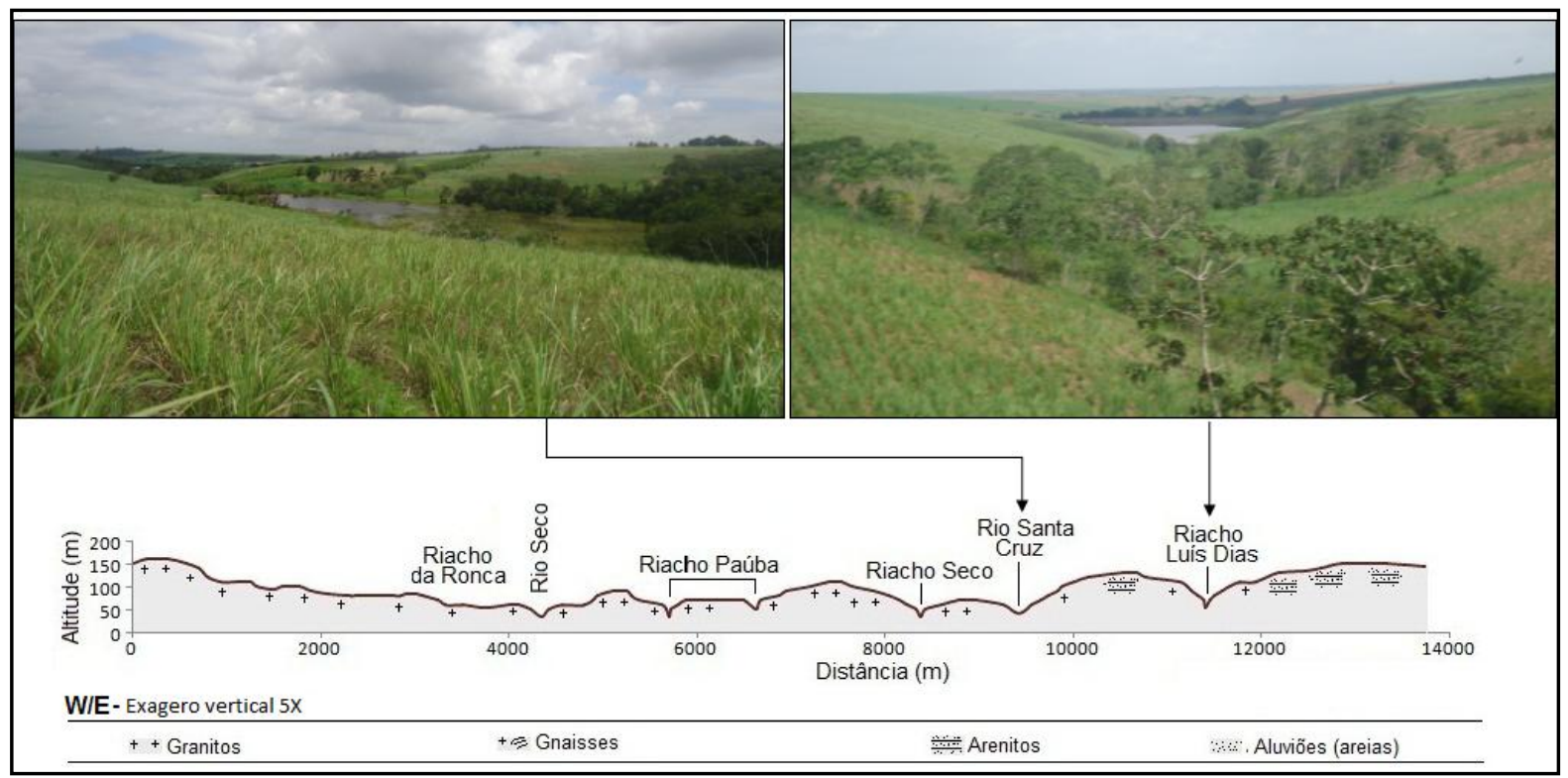

Figura 13 - Perfil C - UTM 9249000. Observar nas imagens as encostas do rio Santa Cruz e Riacho Luís Dias ambas ocupadas por monocultura de cana-de-açúcar. Notar também que nos dois canais há formas semelhantes de represamento e presença de algumas árvores no leito dos canais.

No perfil D, (Figura 14) orientação W/E, porção sul da carta, foi identificado as menores altitudes, não excedendo $80 \mathrm{~m}$, compreendendo uma linha de colinas. Nesse trecho ocorre um número expressivo de canais delimitados por interflúvios assimétricos, configurando um circuito de vales paralelos e alongados, como o que ocorre no início do perfil na planície do vale do rio Mamanguape, onde estão postas ombreiras em ambas as bordas que delimitam a planície.

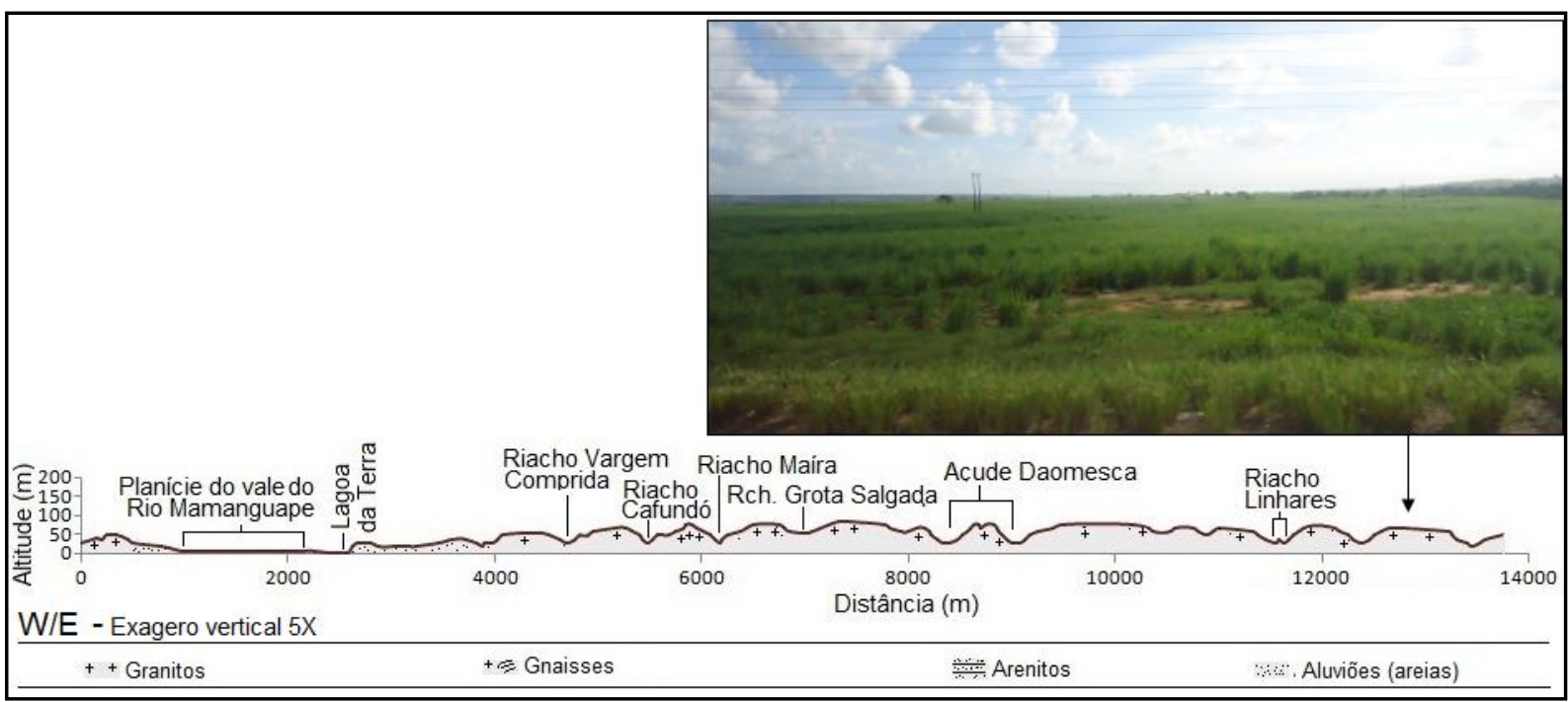

Figura 14 - Perfil D - UTM 9240000. Neste trecho foram observadas as menores altitudes. Observar a sequência de vales assimétricos e o detalhe da foto que registra monocultura de cana-de-açúcar num tabuleiro levemente basculado na porção leste do perfil. 


\section{Carta hipsométrica e rede de drenagem}

A rede de drenagem é constituída por uma malha de afluentes poucos entalhados na porção sul do rio Mamanguape, onde a altimetria não excede $80 \mathrm{~m}$. Já na porção norte os canais são mais volumosos e acentuados, ajustados por linhas de falhas na estrutura das rochas (Npi) e nas rochas da Formação Barreiras. O rio Seco, cuja nascente encontra-se no extremo NW da carta, seguindo o seu curso em direção ao $\mathrm{SE}$, possui um número expressivo de afluentes configurando uma bacia de drenagem em treliça, onde seus afluentes estão ajustados por falhas. Sua bacia apresenta um elevado gradiente hidráulico, sobretudo em função de sua localização no entorno da encosta erodida do Episódio Itapororoca, representado por um alto topográfico onde a altimetria é superior a $170 \mathrm{~m}$ em alguns pontos. Nessa parte do terreno a superfície dômica estrutura uma drenagem radial centrífuga que difere das outras drenagens presentes na região (Figura 15).

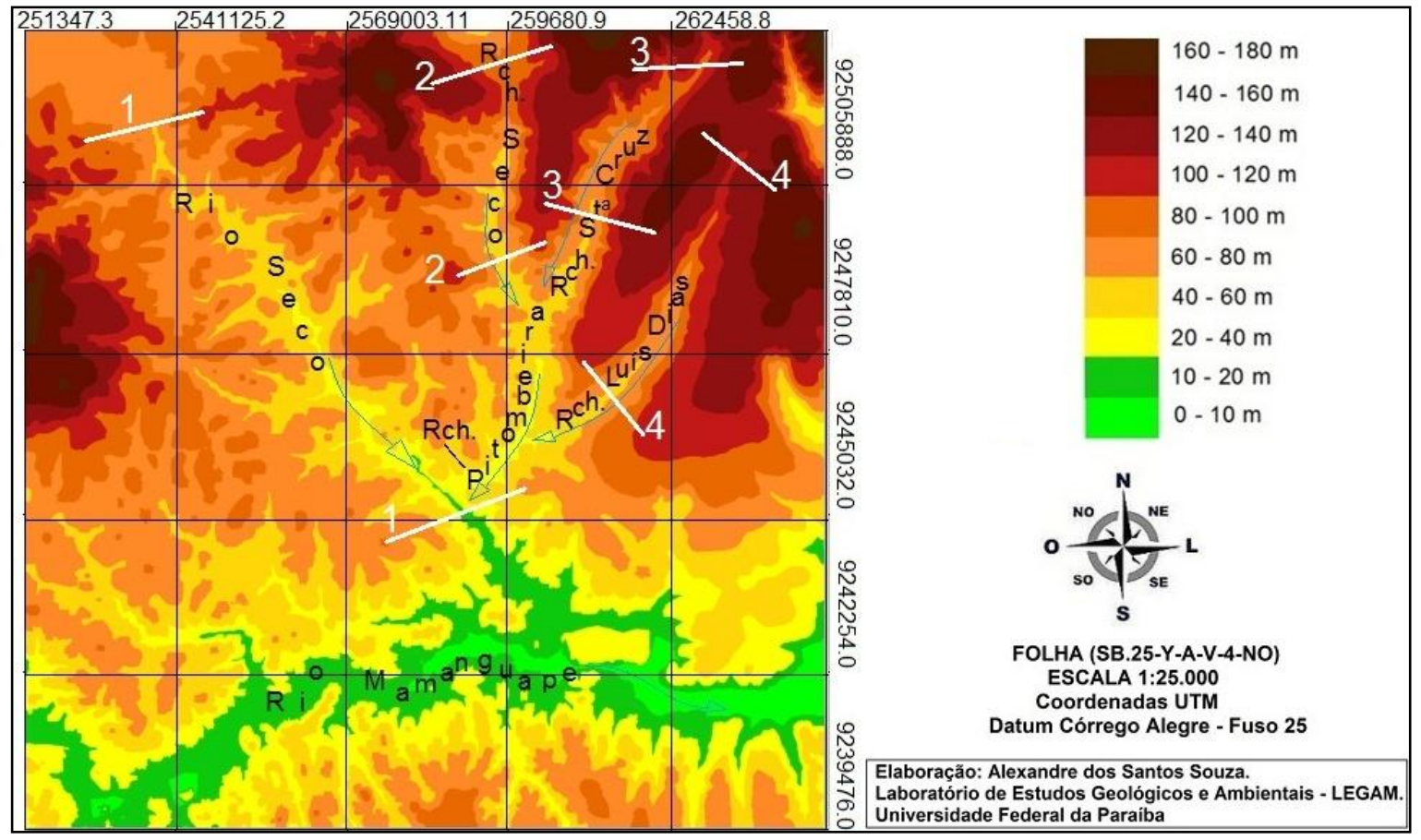

Figura 15 - Carta hipsométrica. Nota: Os trechos sinalizados pelos traçados 1, 2, 3 e 4 correspondem aos vales em seus respectivos altos e baixos cursos, onde foi aplicado o índice RFAV. Org.: Souza (2013).

No nordeste da carta, o rio Santa Cruz, bem como os Riachos Luís Dias e Seco, são evidências conspícuas da ação tectônica ocorrida no local. Esses canais seguem sentidos discordantes do padrão de drenagem regional. Nesse compartimento, os canais apresentam um número reduzido de tributários, se comparados ao padrão geral de drenagem regional, principalmente o Riacho Luís Dias, cujo padrão é paralelo e retilíneo e, apesar de sua considerável extensão, apresenta apenas dois pequenos tributários e uma relativa inexistência de alteração no traçado 
do vale que o confina. Esses canais seguem um sentido atípico N/S e NE/SW, formando um padrão centrípeto convergindo para o canal do Riacho Pitombeira, confluindo no rio Seco e configurando a principal malha hidrográfica tributária do rio Mamanguape.

\section{Indícios de neotectônica}

A Neotectônica, ramo da Geologia Estrutural que se dedica às atividades crustais ocorridas no Terciário Superior até o Quaternário, são típicas das zonas tectonicamente ativas, todavia, mesmo em áreas estáveis, como é o caso do Brasil, é possível encontrar fortes indícios recentes de movimentação crustal (SUGUIO, 1998).

De acordo com Saadi (1991), os primeiros trabalhos de maior expressão sobre a neotectônica brasileira datam de meados de 1951 onde foram feitas associações entre parâmetros geológicos e geomorfológicos além da interpretação da configuração de grandes redes hidrográficas do Brasil por Freitas (1951) e Guimarães (1951), respectivamente.

No caso particular da Folha Itapororoca, objeto central da análise da presente pesquisa, foi possível averiguar aspectos que indicam a possibilidade de ação morfotectônica condicionando alguns aspectos da morfologia do relevo e dos canais de drenagem da região. Tais evidências foram observadas pela nítida presença de diversas feições, como recuos de cabeceiras e canais inflexionados e retilíneos.

Além disso, foram aplicados cálculos de Razão Fundo/Altura do Vale (RFAV) sobre os canais dos rios Seco e Santa Cruz, bem como nos Riachos Seco e Luís Dias, utilizando os parâmetros propostos por Bull e McFadden (1977 apud WELLS et al., 1988), ressalvando-se que essa técnica de avaliação de intensidade neotectônica ainda tem sido pouco aplicada em trabalhos no Brasil, dentre os quais estão os publicados recentemente por Barbosa e Furrier (2012).

O índice de RFAV consiste em um cálculo morfométrico recomendado para análise em áreas fluviais onde são cruzados os dados correspondentes à altura dos interflúvios (direito e esquerdo) em relação ao talvegue, largura do vale e altura do fundo do vale referente à primeira cota altimétrica, (conforme ilustrado na Figura 16).

O cálculo de Razão Fundo/Altura de Vale (RFAV), corrobora para indicar que os valores menores que 1 podem ser considerados indicadores de neotectonismo, enquanto que os valores maiores que 1 correspondem a áreas de estabilidade tectônica onde predominam fatores exógenos. Recentemente, Silva et al. (2003) utilizou esse parâmetro no sudeste da Espanha, Leste da cordilheira Bética, como indicativo de tectônica ativa. 


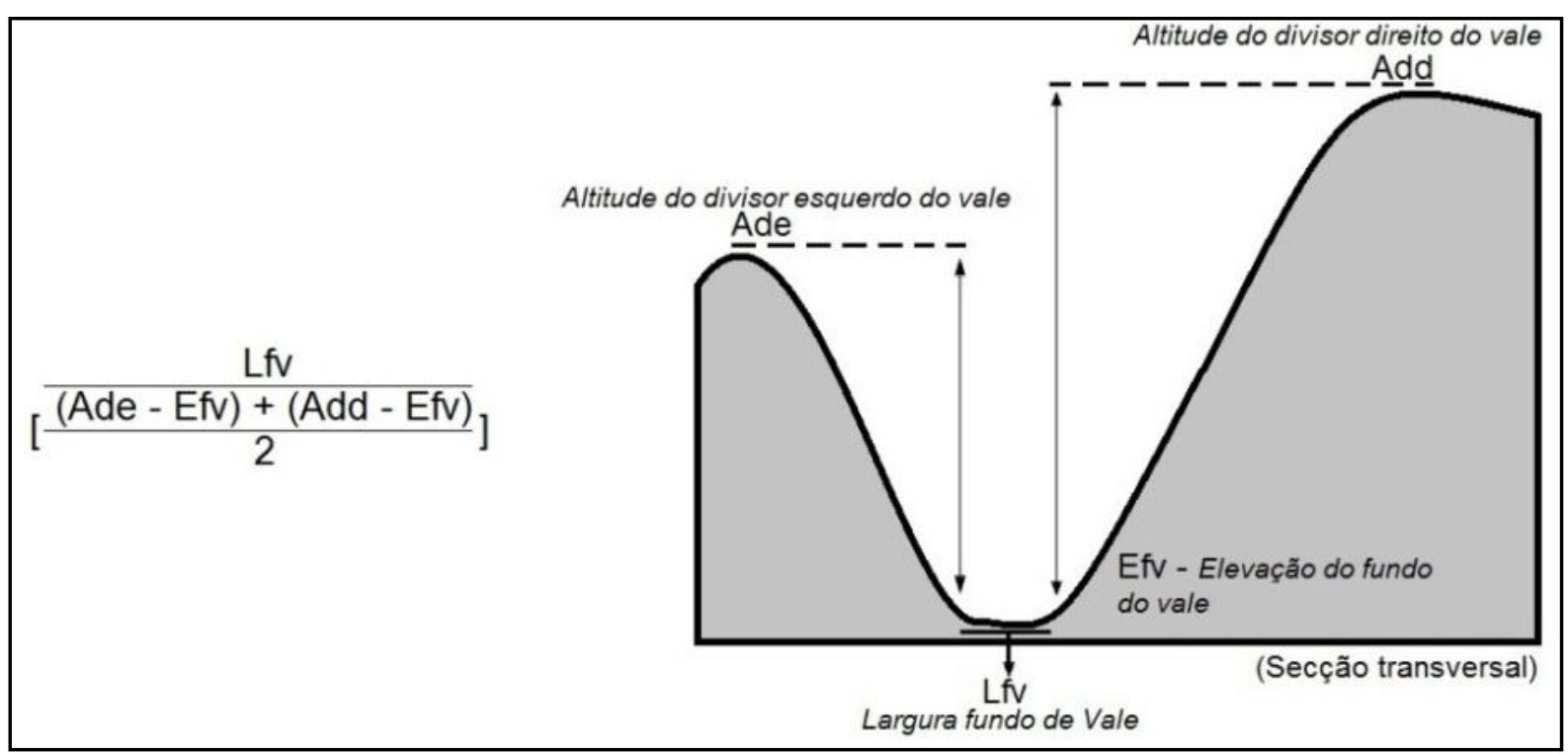

Figura 16 - Expressão matemática e procedimento de medida para encontrar o índice morfométrico RFAV. Fonte: Adaptado de Bull e McFadden (1977 apud WELLS et al., 1988).

Na folha Itapororoca, o cálculo RFAV foi aplicado em oito perfis, cortando paralelamente vales distintos (Figura 15), onde foram delimitados os divisores de água dos lados opostos dos canais selecionados, a partir dos valores de referência das curvas de nível e pontos cotados (conforme orientação Figura 16).

Tabela 2 - Valores obtidos com o cálculo RFAV

\begin{tabular}{cccccc}
\hline TRECHOS & Lfv & Ade & Add & Efv & RFAV \\
\hline 1 Riacho Seco (alto curso) & $100 \mathrm{~m}$ & $1.350 \mathrm{~m}$ & $650 \mathrm{~m}$ & $\begin{array}{c}100 \\
\mathrm{~m}\end{array}$ & 0,11111 \\
1 Riacho Seco (baixo curso) & $150 \mathrm{~m}$ & $775 \mathrm{~m}$ & $725 \mathrm{~m}$ & $50 \mathrm{~m}$ & 0,21428 \\
\hline 2 rio Santa Cruz (alto curso) & $150 \mathrm{~m}$ & $1.250 \mathrm{~m}$ & $1.000 \mathrm{~m}$ & 100 & 0,15384 \\
2 rio Santa Cruz (alto curso) & $125 \mathrm{~m}$ & $950 \mathrm{~m}$ & $1.050 \mathrm{~m}$ & $60 \mathrm{~m}$ & 0,13297 \\
\hline 3 Riacho Luís Dias (alto curso) & $125 \mathrm{~m}$ & $775 \mathrm{~m}$ & $1.600 \mathrm{~m}$ & 120 & 0,11241 \\
3 Riacho Luís Dias (baixo curso) & $75 \mathrm{~m}$ & $450 \mathrm{~m}$ & $1.025 \mathrm{~m}$ & $50 \mathrm{~m}$ & 0,10909 \\
\hline 4 rio Seco (alto curso) & $175 \mathrm{~m}$ & $775 \mathrm{~m}$ & $175 \mathrm{~m}$ & $65 \mathrm{~m}$ & 0,16706 \\
4 rio Seco (baixo curso) & $62,5 \mathrm{~m}$ & $1.350 \mathrm{~m}$ & $900 \mathrm{~m}$ & $20 \mathrm{~m}$ & 0,05656 \\
\hline
\end{tabular}

Fonte: Adaptado de Sudene (1974).

Nesta perspectiva, considerando que a margem continental brasileira é do tipo passiva e observando os resultados obtidos nas vertentes dos riachos Seco e Luís Dias, e dos rios, Santa Cruz e Seco, em seus respectivos altos e baixos cursos, levando em consideração que a área de estudo não apresenta altitudes superiores a $185 \mathrm{~m}$, foram obtidos valores extremante baixos, conforme apresentado na Tabela 2, fato que corrobora fortemente para 
uma provável influência de tectônica recente. Desta forma levanta-se a hipótese de que os estudos neotectônicos no Brasil devem ser considerados em análises semelhantes onde o fator climático/exógeno, por si só, não explicam as morfologias das bacias hidrográficas encontradas.

\section{CONSIDERAÇÕES FINAIS}

Na região compreendida pela carta topográfica de Itapororoca, foi possível apresentar, por meio dos parâmetros utilizados, formas distintas de um relevo trabalhado por agentes externos e internos que atuam na estrutura crustal. A partir dos dados obtidos na pesquisa, foi possível apresentar uma caracterização da unidade geomorfológica em questão, partindo de sua base geológica, correlacionando-a com a morfogenia do relevo que demonstra estar sobre possível controle morfotectônico.

Para tanto, a produção dos perfis topográficos (ao longo de sentido longitudinal e latitudinal à área de estudo) a partir da Folha Itapororoca 1:25.000, a aplicação de parâmetros morfométricos e a análise do mapeamento apresentado, foram de grande relevância, pois possibilitou a constatação de feições típicas de áreas onde é imprescindível o planejamento do meio físico.

Destarte, a presente análise expôs com clareza pontos importantes que devem ser observados pelas partes interessadas na gestão e manejo da região em questão, entre os quais podem ser sumarizados:

$\checkmark$ Base litológica que congrega rochas do tipo: Granitóide de quimismo indiscriminado (Npi); Gnássico-Migmatito (Pgm/py); Vulcânica Félsica Itapororoca (Ki); coberturas elúvio-coluviais $(\mathrm{Qe})$, aluviões (Qa). Tal característica origina unidades morfológicas distintas, que forma sumarizadas em 4 tipos: formas tabulares; colinas médias e suaves; domo do episódio vulcânico Itapororoca; e planície fluvial.

$\checkmark$ Considerável similaridade nos aspectos climáticos (com pluviosidade média anual de $1.634 \mathrm{~mm}$ ) e na vegetação (bastante degradada) dos municípios que abrangem a Folha Itapororoca (Rio Tinto, Mamanguape, Cuité de Mamanguape, Itapororoca, Capim e Curral de Cima). Dessa forma, levanta-se a hipótese de que o relevo local não pode ser explicado apenas pelo fator climático.

$\checkmark$ Tipos de solo com texturas que vão da argilosa até a arenosa, demonstrando variação de cores e maior ou menor fertilidade, em função do saprólito e do processo 
pedogenético. Na região, a capacidade de uso e manejo do solo possibilita diversas atividades agropastoris.

$\checkmark$ Constatação de áreas com ocupação de vertentes com forte declividade, retirada de matas ciliares e antropização de leitos fluviais provocadas por atividades agropastoris, fatos que afetam o equilíbrio físico-natural da região, configurando zonas de susceptibilidade e vulnerabilidade ambiental, como é o caso do rio Mamanguape e seus tributários, que recebem esgotos domésticos, industriais, resíduos agroindustriais, defensivos químicos das culturas irrigadas, acelerando os processos de eutrofização.

$\checkmark$ Observação das áreas com maior e menor grau de declividades, por meio da carta clinográfica. Esse mapeamento permitiu análise gráfica da orientação das vertentes, possibilitando uma melhor compreensão e possibilidade de equacionamento dos problemas que ocorrem na região, além do planejamento de uso e ocupação do solo.

$\checkmark$ A rede de drenagem é constituída por uma malha de afluentes poucos entalhados na porção sul do rio Mamanguape, onde a altimetria não excede $80 \mathrm{~m}$. Já na porção norte, a altitude alcança $175 \mathrm{~m}$ em alguns pontos, os canais fluviais são mais volumosos e extensos, drenando para o rio Mamanguape, que segue num sentido exorreico. A observação em campo verificou que, nos rios e riachos da região, faz-se necessário um plano de recuperação de matas ciliares e revitalização, pois os leitos apresentam fortes indícios de antropização.

$\checkmark$ Averiguação de evidências que indicam a possibilidade de ação morfotectônica condicionando alguns aspectos da morfologia do relevo e dos canais de drenagem da região, com presença de diversas feições, entre elas: recuos de cabeceiras, canais inflexionados e retilíneos, direções anômalas nos cursos d'água e valores morfométricos (RFAV) que corroboram a influência de ação neotectônica na área. Por essas razões, ressalta-se a grande possibilidade de tais constatações estarem relacionadas a reativações recentes.

E, para concluir, vale salientar que esta análise não visa, em hipótese alguma, encerrar a questão pertinente ao estudo da área em questão, mas, sim, propiciar um meio pelo qual novos trabalhos sejam desenvolvidos no afã de apresentar informações que corroborem com os resultados aqui apresentados, permitindo, assim, o conhecimento pormenorizado da região de maneira que os processos naturais e antrópicos possam ser conhecidos e planejados visando o bem comum. 


\section{REFERÊNCIAS BIBLIOGRÁFICAS}

AB'SÁBER, A. N. A. O relevo brasileiro e seus problemas. In: AZEVEDO, A. de et al. (Dir.) Brasil, a terra e o homem. São Paulo: Companhia Editora Nacional, 1964. v. 1 - As bases físicas, p. 135-250.

AESA - AGÊNCIA EXECUTIVA DE GESTÃO DAS ÁGUAS DO ESTADO DA PARAÍBA, 2004. Disponível em: <http://www.aesa.pb.gov.br/comites/litoral norte/proposta.pdf $>$. Acesso em: 2 maio 2013.

ARGENTO, M. S. F. Mapeamento geomorfológico: In: GUERRA, A. J. T.; CUNHA, S. B. Geomorfologia: uma atualização de bases e conceitos. 7. ed. Rio de Janeiro: Bertrand Brasil, 2007, p. 365-390.

ASMUS, H. E.; PONTE, F. C. The Brazilian marginal basins. In: NAIRN, A. E. M.; STEHLI, F. G. (Orgs.). The ocean basins and margins. The South Atlantic, Nova York: Plenum Press, v. 1, p. 87-133, 1973.

BARBOSA, M. E. F.; FURRIER, M. Técnicas de geoprocessamento e morfometria aplicados na detecção de atividades neotectônicas no grupo barreiras, estudo da bacia hidrográfica do Rio Guruji (PB). ACTA Geográfica, Boa Vista, v. 6, n. 11, p.117-131, jan./abr. 2012.

BEZERRA, F. H. R.; MELLO, C. L.; SUGUIO, K. A Formação Barreiras: recentes avanços e antigas questões. Geol. USP, Sér. Cient. [online], v. 6, n. 2, p. III-VI, 2006.

BRASIL. Ministério da Agricultura. EPFS - Equipe de Pedologia e Fertilidade do Solo. Levantamento exploratório - reconhecimento de solos do Estado da Paraíba \& interpretação para uso agrícola dos solos do Estado da Paraíba. Rio de Janeiro, 1972. (Boletim técnico n. 15).

BRITO NEVES, B. B.; CAMPOS NETO, M. C.; VAN SCHMUS, W. R.; SANTOS, E. J. O sistema Pajeú-Paraíba e o Maciço São José do Campestre no Leste da Borborema. Revista Brasileira de Geociências, v. 31, n. 2, p. 173-184, 2001.

; RICCOMINI, C.; FERNANDES, T. M. G.; SANT' ANNA, L. G. O Sistema Tafrogênico Terciário do Saliente Oriental Nordestino na Paraíba: um legado Proterozóico. Revista Brasileira de Geociências, v. 34, p. 127-134, 2004. 
; MANTOVANI, M. S. M.; MORAES, C. F. de; SIGOLO, J. B. As anomalias geológicas e geofísicas localizadas ao norte de Itapororoca. Revista Brasileira de Geociências, v. 38, n. 1, mar. 2008.

; VAN SCHMUS, W. R.; SANTOS, E. J.; CAMPOS NETO, M. C; KOZUCH, M. O evento Cariris Velhos na Província Borborema: integração de dados, implicações e perspectivas. Revista Brasileira de Geociências, v. 25, n. 4, p. 279-296, dez. 1995.

CHRISTOFOLETTI, A. Geomorfologia - 2a ed. - São Paulo: Editora Blucher, 1980, p. 102-110. Aplicabilidade do conhecimento geomorfológico nos projetos de planejamento. In: GUERRA, A. J. T.; CUNHA, S. B. Geomorfologia: uma atualização de bases e conceitos. 7. ed. Rio de Janeiro: Bertrand Brasil, 2007. p. 415-437.

CPRM - SERVIÇO GEOLÓGICO DO BRASIL. Geologia e recursos minerais do Estado da Paraíba. Recife: CPRM, 2002.

. Projeto Cadastro de Fontes de Abastecimento por Água Subterrânea: Estado da Paraíba. Recife: CPRM/Prodeem, 2005.

DE BIASI, M. Carta de declividade de vertentes: confecção e utilização. Geomorfologia. São Paulo, v. 21, p. 8-13, 1970.

EMBRAPA - EMPRESA BRASILEIRA DE PESQUISA AGROPECUÁRIA. Centro Nacional de Pesquisa de Solos. Sistema Brasileiro de Classificação de Solos. Brasília: Embrapa SPI; Rio de Janeiro: Embrapa Solos, 1999.

. Centro Nacional de Pesquisa de Solos. Sistema Brasileiro de Classificação de Solos.

2. ed. Rio de Janeiro: Embrapa-SPI, 2006.

. Manual de métodos de análises de solo. 2. ed. Rio de Janeiro: Embrapa Solos, 1997.

FREITAS, R. O. de. Ensaio sobre a tectônica moderna do Brasil. Boletim FFCL/USP, v. 130, n. 6, 1951.

FURRIER, M.; ARAUJO, M. E.; MENESES, L. F. Geomorfologia e tectônica da Formação Barreiras no estado da Paraíba. Geologia USP - Série Científica, v. 6, p. 61-70, 2006. 
GUERRA, A. T.; GUERRA, A. J. T. Novo dicionário geológico-geomorfológico. Rio de Janeiro: Bertrand Brasil, 1997.

GUIMARÃES, D. Arqui-Brasil e sua evolução geológica. Boletim DNPM/DFPM. Rio de Janeiro, n. 88, p. 1-314. 1951.

HASUI, Y; PONÇANO, W. L. Geossuturas e sismicidade no Brasil. ABGE, Anais do Cong. Bras. Geol. Eng., São Paulo, v. 1, p. 331-338, 1978.

HERZ, R.; DE BIASI, M. Critérios e legendas para macrozoneamento costeiro. Brasília: Ministério da Marinha/Comissão Interministerial para Recursos do Mar, 1989.

IBGE - INSTITUTO BRASILEIRO DE GEOGRAFIA E ESTATÍ́STICA. Manual técnico de Pedologia. 2. ed. Rio de Janeiro: Coordenação de Recursos Naturais e Estudos Ambientais, 2007.

MAIA, R. P.; BEZERRA, F. H. R. Neotectônica, geomorfologia e sistemas fluviais: uma análise preliminar do contexto nordestino. Revista Brasileira de Geomorfologia, v. 12, n. 3, p. 37-46, 2011.

PENHA, H. M. Processos endogenéticos na formação do relevo. In: GUERRA, A. J. T.; CUNHA, S. B. Geomorfologia: uma atualização de bases e conceitos. 7. ed. Rio de Janeiro: Bertrand Brasil, 2007, p. 51-91.

ROSS, J. L. S. Geomorfologia, ambiente e planejamento. São Paulo: Contexto, 1992.

SAADI, A. Neotectônica da plataforma brasileira: esboço e interpretação preliminares. Geonomos, v. 1, p. 1-15, 1991.

SANTOS, E. J.; NUTMAN, A. P.; BRITO NEVES, B, B. Idades SHRIMP U-Pb do Complexo Sertânia: implicações sobre a evolução tectônica da zona transversal, Província Borborema. Geol. USP: Série Científica. São Paulo, v. 4, n. 1, p. 1-12, abr. 2004.

Santos, E. J., Geologia e Recursos Minerais do Estado da Paraíba/Organizado por Edilton José dos Santos, Cicero Alves Ferreira, José Maria Ferreira da Silva Júnior - Recife: CPRM, 2002. 142 p. il. 2 mapas. Escala 1:500.000 
SILVA, P. G., GOY, J.L., ZAZO, C., BARDAJM, T. Fault generated mountain fronts in Southeast Spain: geomorphologic assessment of tectonic and earthquake activity. Geomorphology, v. 250, p. 203-226, 2003.

SUDENE - SUPERINTENDÊNCIA DE DESENVOLVIMENTO DO NORDESTE. Divisão de Recursos Naturais. Serviço de Cartografia. Folha Itapororoca (SB.25-Y-A-V-4-NO), Recife: Sudene, 1974.

SUGUIO, K. Dicionário de Geologia Sedimentar e áreas afins. Rio de Janeiro: Bertrand Brasil, 1998.

A Importância da Geomorfologia em Geociências e áreas afins. Revista Brasileira de Geomorfologia, v. 1, n. 1, p. 80-87, 2000.

WELLS, S. G.; BULLARD, T. F.; MENGES, C. M.; DRAKE, P. A.; KARAS, K. I.; KELSON, K. I.; RITTER, J. B.; WESLING, J. R. Regional variations tectonic geomorphology along a segmented convergent plate boundary, pacific coast of Costa Rica. Geomorphology, Amsnterdam: Elsevier Science Publishers B. V., 1988. p. 239-265.

Artigo recebido em 02/09/2013.

Artigo aceito em 30/09/2013. 